\title{
A túlfújt endotrachealis mandzsetta szerepe a légcsősérülések diagnosztikájában
}

\author{
Rieth Anna dr. ${ }^{1}$ - Ottlakán Aurél dr. ${ }^{3}$ - Kovács Tamás dr. ${ }^{1}$ \\ Balogh Brigitta dr. ${ }^{1}$ - Furák József dr. ${ }^{2}$ \\ 'Szegedi Tudományegyetem, Általános Orvostudományi Kar, Gyermekklinika, Gyermeksebészet, Szeged \\ ${ }^{2}$ Szegedi Tudományegyetem, Általános Orvostudományi Kar, Sebészeti Klinika, Mellkassebészet, Szeged \\ ${ }^{3}$ Szegedi Tudományegyetem, Általános Orvostudományi Kar, Sebészeti Klinika, Szeged
}

\begin{abstract}
A tracheobronchialis sérülések ritkák, de életveszélyes állapotot jelenthetnek. Leggyakoribb okaik a nyaki vagy mellkasi, nagy energiájú tompa trauma, a nehéz intubálás vagy az intratrachealis tubus és gyomorszonda együttes viselése. A korai diagnózis és a megfelelő kezelés életmentő lehet, e sérülések felismerése azonban az atípusos tünetek és a súlyos társsérülések miatt gyakran elhúzódik. Típusos esetekben a fizikális vizsgálat során progresszív, kiterjedt subcutan emphysema hívhatja fel rájuk a figyelmet. További nehézséget jelent, hogy a radiológiai jelek nem elég specifikusak, a komputertomográfís felvételeken pedig a leggyakrabban csupán subcutan emphysema, pneumomediastinum vagy esetenként pneumothorax látható. Cikkünkben három eset kapcsán mutatjuk be a tracheobronchialis sérüléseket - egy baleseti, egy nehéz intubációs légúti sérülés, illetve egy tracheooesophagealis fistula kialakulása során. Az endotrachealis tubus ballonja a tracheafal rupturája mentén mindegyik esetben túlfújhatóvá vált, így a légút falán kívülre terjedt - ez a képalkotó vizsgálatokon láthatóvá is vált. Ez egy ritka, de direkt és egyértelmú jele a légúti sérüléseknek, mely alapján a trachea teljes falvastagságának szakadására lehet számítani. Cikkünkben a túlfújt ballon diagnosztikus jelentőségére szeretnénk rávilágítani.
\end{abstract}

Orv Hetil. 2020; 161(25): 1063-1068.

Kulcsszavak: túlfújt ballon, endotrachealis ballon, tracheasérülés, légúti sérülés

\section{The role of an overinflated endotracheal tube in the diagnosis of tracheal injuries}

Tracheobronchial injury is an uncommon, but often life-threatening condition. It is mostly caused by blunt thoracic or neck trauma, difficult or prolonged intubation associated with nasogastric tube insertion. An early diagnosis and treatment can be lifesaver. The diagnosis is often late because of atypical symptoms and unspecific radiological signs, and due to the presence of severe coexistent injuries. Generally, the classic hallmark during physical examination is a progressive, extensive surgical emphysema. Radiological signs are often atypical, which makes the diagnosis more difficult. The most frequent signs found on computed tomography are also unspecific, mostly surgical emphysema, pneumomediastinum or pneumothorax may be noted. We present three patients suffering from airway laceration caused by car accident, difficult intubation, and prolonged utilization of nasogastric and endotracheal tube. All the patients had an overdistended endotracheal balloon herniated outside the extratracheal space along the rupture of the tracheal wall. These external balloons were all detected on radiography. This is a direct and pathognomic sign of airway injury, suggesting complete rupture in the tracheal wall. In our report, we would like to highlight the diagnostic role of an overinflated cuff.

Keywords: overinflated cuff, endotracheal cuff, endotracheal balloon, tracheal lesion, airway injury

Rieth A, Ottlakán A, Kovács T, Balogh B, Furák J. [The role of an overinflated endotracheal tube in the diagnosis of tracheal injuries]. Orv Hetil. 2020; 161(25): 1063-1068.

(Beérkezett: 2020. január 30.; elfogadva: 2020. február 29.) 


\section{Rövidítések}

ATLS = (Advanced Trauma Life Support) a súlyos sérültek primer ellátásának protokollja; $\mathrm{CT}=$ (computed tomography $)$ számítógépes tomográfia; $\mathrm{ECMO}=($ extracorporeal membrane oxygenation) extracorporalis membránoxigenizáció; eFAST = (Extended Focused Assessment with Sonography in Trauma) fókuszált kiterjesztett traumatológiai ultrahangvizsgálat; ETT $=$ endotrachealis tubus; GCS $=($ Glasgow Coma Scale $)$ Glasgow Kóma Skála; MDCT = (multi-slice detector computed tomography) többszeletes detektoros számítógépes tomográfia; RSI $=$ (rapid sequence intubation $)$ gyors szekvenciális intubálás; $\mathrm{TEF}=($ tracheoesophageal fistula $)$ tracheooesophagealis fistula

A légút sérülésének számos oka lehet. A trauma miatt kialakuló ruptura tompa mellkasi vagy nyaki sérüléshez köthető, ez a legtöbbször autóbaleset, motorbaleset vagy magasból leesés következménye. Az érintettek többsége a helyszínen életét veszti (30-80\%) [1]. A kialakult inkomplett tracheasérülést az intubáció súlyosbíthatja, ezzel a légút falának teljes szeparációját okozhatja. Traumától függetlenül, egy nehéz intubációs helyzet önmagában is légúti sérüléshez vezethet, ekkor a tubus vége vagy a hirtelen, nagy nyomással felfújt ballon okozza a trachea laesióját [2]. Továbbá az endotrachealis tubus (ETT) és a nasogastricus szonda hosszan tartó használata tracheooesophagealis fistula (TEF) kialakulását okozhatja. Mindhárom fentebb leírt esetben az endotrachealis mandzsetta (cuff) a ruptura mentén túlfújódhat, és a légút falán kívülre herniálódhat. Radiológiai vizsgálatokkal ez a túlfújt ballon már korán észlelhető.

Általánosságban elmondható, hogy a tracheobronchialis sérülések esetén a gyors diagnózis életmentő lehet, de az atípusos tünetek és az indirekt radiológiai jelek megnehezítik a klinikus munkáját [1]. Ezért fontos a röntgen-, illetve CT-felvételeken látható hiperinflált ETT-ballon, a trachea falán kívül elhelyezkedő cuff, mivel ezek egyértelmű jelei a légúti sérülésnek.

\section{Esetbemutatás}

\section{Elsö eset}

Egy 9 éves fiú sérült autóbalesetben. A hátsó ülésen bekötve utazott, amikor kisodródtak, és egy fának ütköztek. A helyszínen újraélesztették, és RSI (rapid sequence intubation) szerint intubálták. A primer ellátás során láthatóvá vált a nyakon harántul lefutó contusio, amelyet egyértelműen a biztonsági öv lenyomata képezett. Az elkészült CT-vizsgálaton a nyaktól a mellkasfalon át a hasfalig húzódóan súlyos subcutan emphysema vált láthatóvá. Az ETT ballonja a légút várható méreténél nagyobbra, 2,56 cm-re volt felfújva, míg a trachea átmérője 1,03 cm volt, ezek alapján felmerült a tracheasérülés gyanúja (1. és 2. ábra). Fül-orr-gégész a ballontól mind caudalisan, mind cranialisan kizárta a laesio lehetőségét, a ballon szintjéról azonban nem tudott biztonsággal nyilatkozni, mert a légútvesztés veszélye miatt a beteget

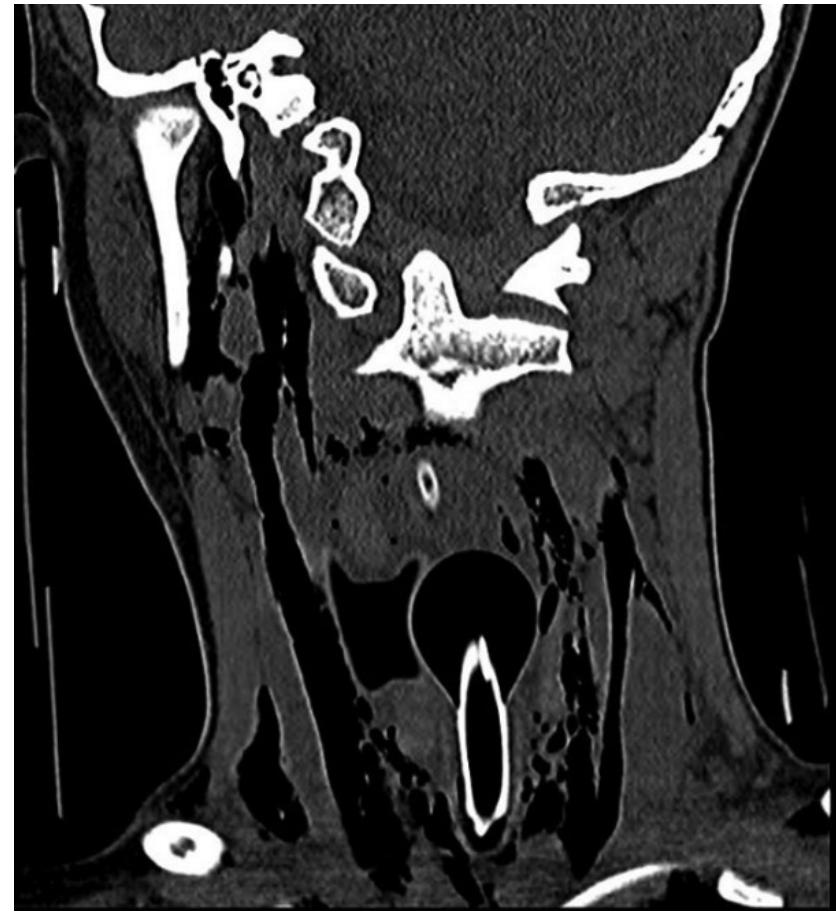

1. ábra Az első beteg CT-vizsgálata során látható a túlfújt ballon és a nyaki lágyrész-emphysema

CT = számítógépes tomográfia

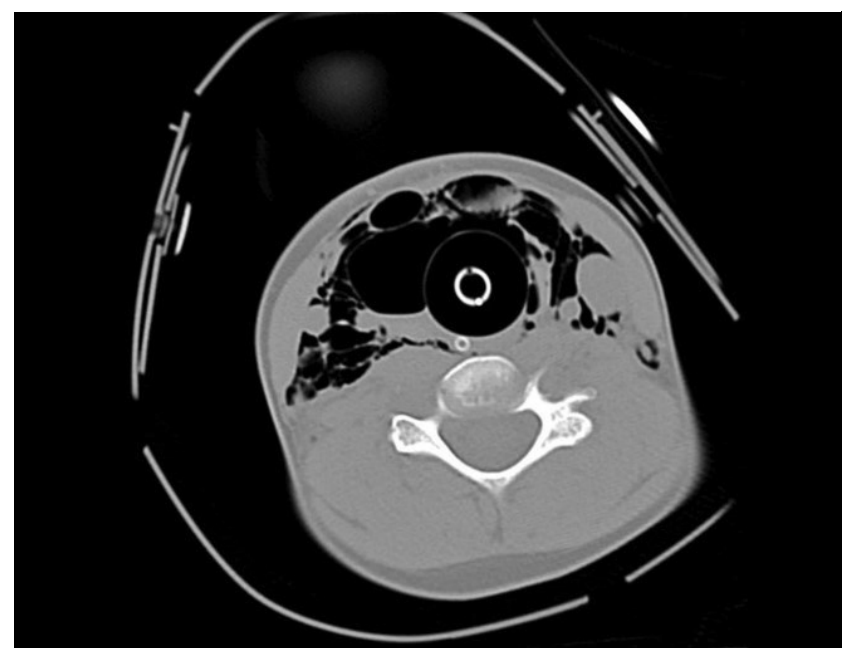

2. ábra Lágyrész-emphysema a túlfújt ballon szintjében, a trachea fala
nem azonosítható a CT-felvételen az első betegnél
CT = számítógépes tomográfia

még rövid időre sem lehetett extubálni. Sürgős mútét során láthatóvá vált a túlfújt ballon, melynek a szintjében a trachea folytonossága megszakadt, a distalis rész $3 \mathrm{~cm}$ rel caudalisabban folytatódott (3. ábra). Ezek alapján valószínúsíthetó, hogy a baleset következtében szakadt szét a trachea, és a két vég szétcsúszása adott helyet a túlfújt cuffnak. A sérülést primeren, feszülésmentes megszakított csomókkal zártuk. A további feszülésmentesség érdekében 3 napig nyaki flexiót alkalmaztunk. Preventív tracheostomia képzése történt. A posztoperatív szakban 

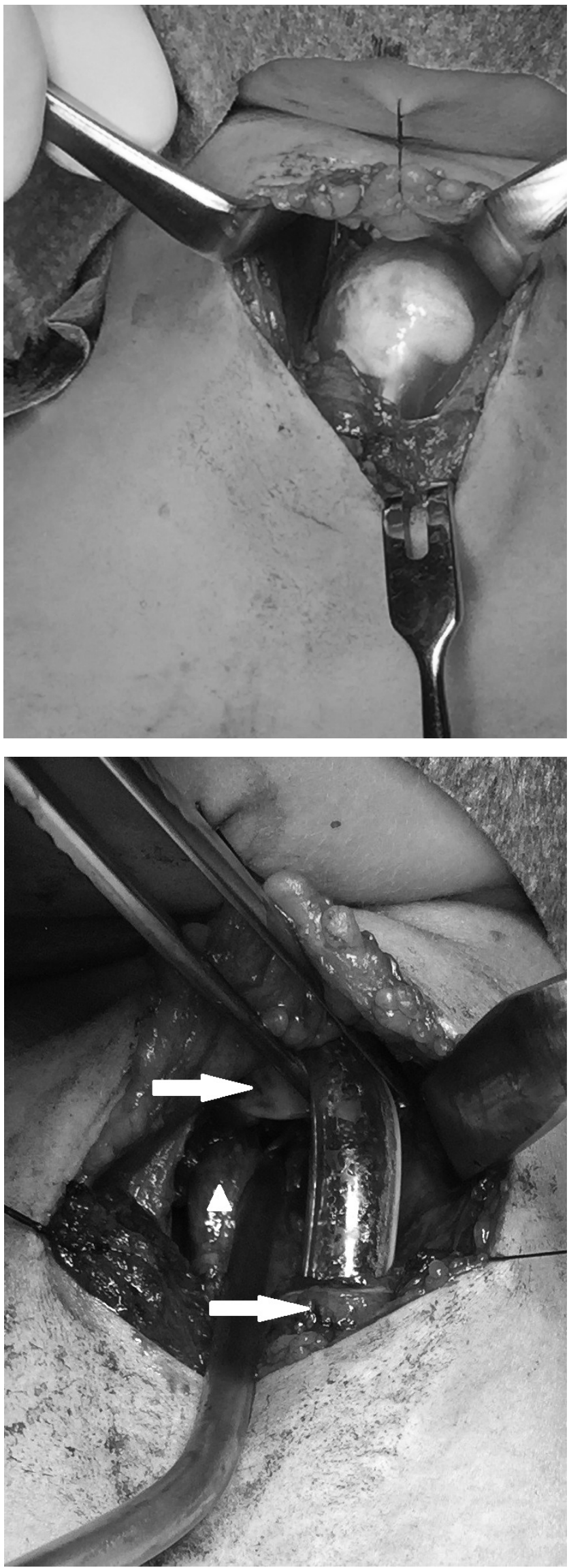

3. ábra

Intraoperatív képek az első betegnél. A nyilak jelölik a két tracheavéget, a háromszög a nyelőcsövet antibiotikumterápia indult, mediastinitis nem fejlődött ki. A mútétet követő 11. napon a gyermeket extubálták, további egy hét múlva a tracheakanült eltávolították, sérüléseiből maradéktalanul felépült.

\section{Második eset}

Egy 31 éves nőbeteget szállítottak a sürgősségi osztályra, aki autójával árokba hajtott. A biztonsági öv nem volt bekötve, a légzsák nem nyílt ki. A helyszínen eszméletlenül (GCS 2-4-1) találták, RSI szerint intubálták. Az elkészült sürgősségi CT alapján a C. I. csigolyán darabos törés volt látható. A nyakon kiterjedt subcutan emphysemát írtak le, amely a mediastinumba, majd a hasfali régióra is ráterjedt. A tubus cuffja $3,24 \mathrm{~cm}$ átmérôjü volt, míg a tubustól distalisan a trachea átmérője $1,53 \mathrm{~cm}$. A cuff túlfújt állapotban, a trachea hátulsó falán kívülre ért (4. és 5. ábra). Fül-orr-gégészeti bronchoszkópos vizsgálat lokalizálta a trachea pars membranacea sérülését. Sürgős mútét során $6 \mathrm{~cm}$ hosszú repedést találtunk a légcső hátulsó falán; a tubus cuffja a sérülés szintjében, de extratrachealisan, a légcső és a nyelőcső között helyezkedett el, disszekálva ezeket egymástól. A légcső sérülését primeren, feszülésmentes, megszakított öltésekkel zártuk. Preventív tracheostomia képzése történt. A posztoperatív szakban antibiotikumterápia indult, mediastinitis, illetve stenosis nem alakult ki.

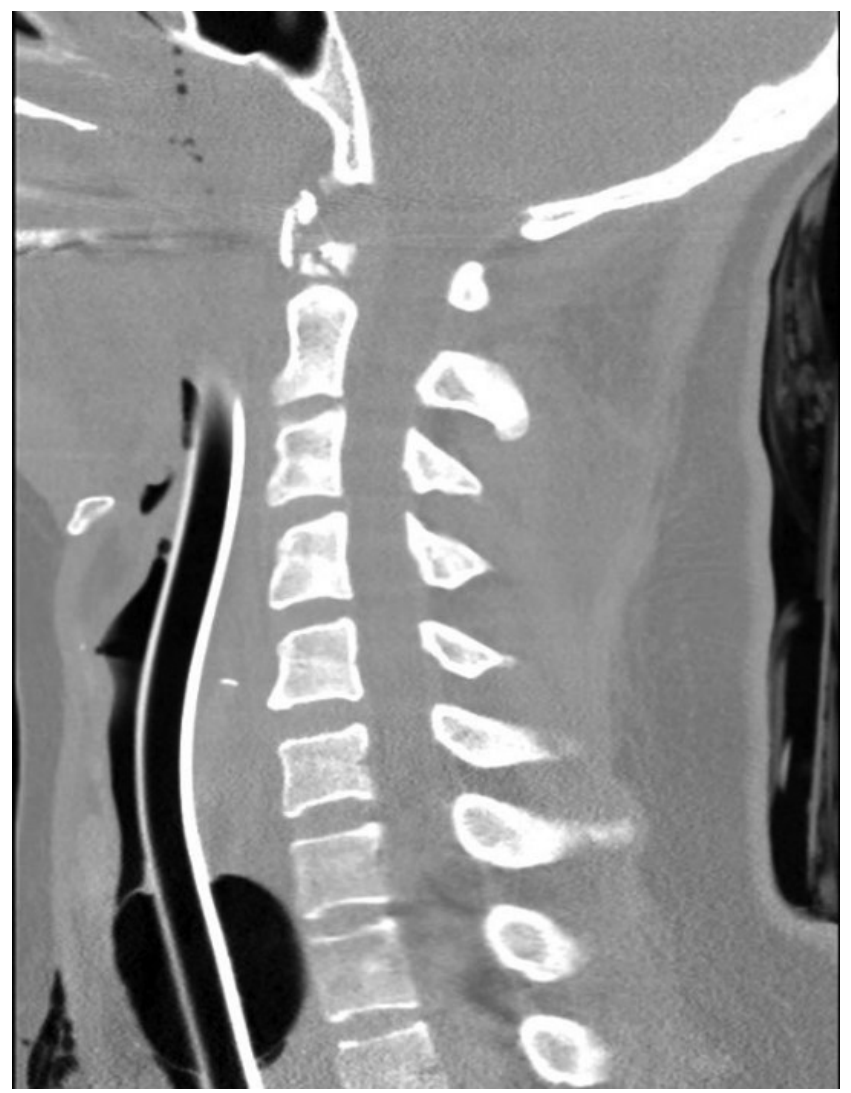

\begin{tabular}{l|l} 
4. ábra & Hátrafelé herniálódott cuff, ami a pars membranacea sérülésére
\end{tabular} utal a második esetben 


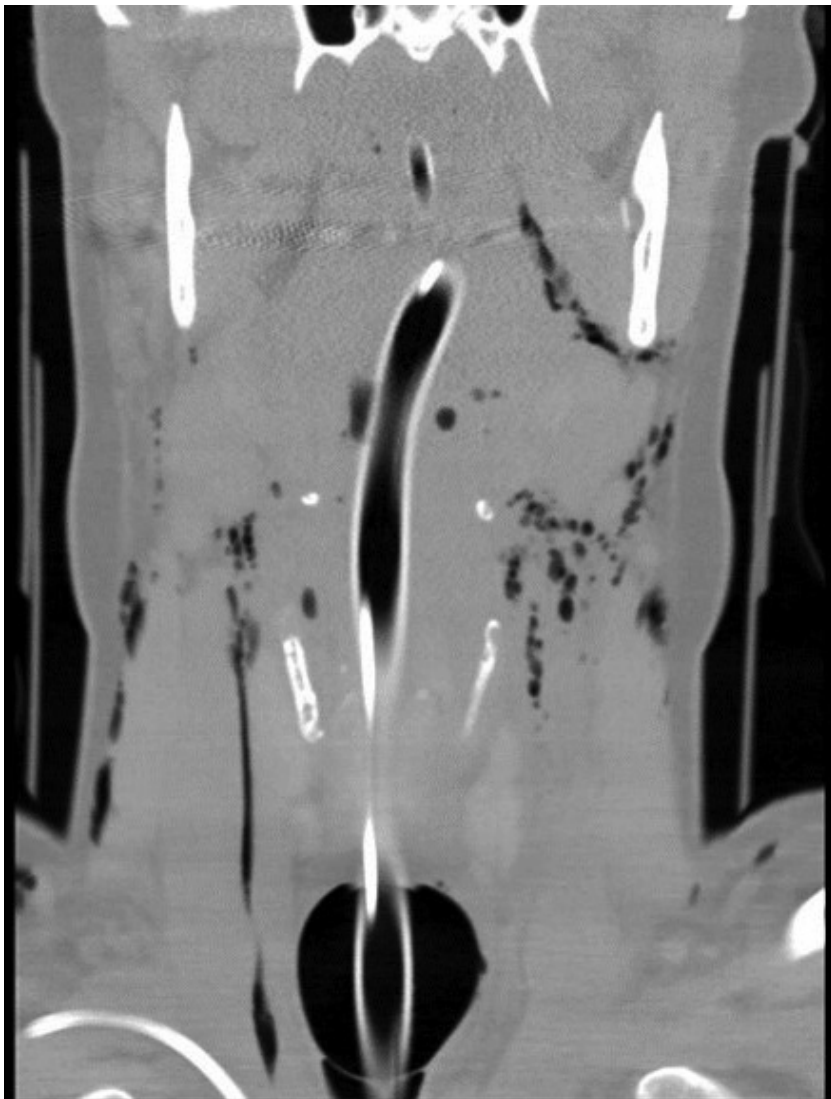

5. ábra

\section{Harmadik eset}

Egy 76 éves nőbetegnél intubálást és nasogastricus szondát alkalmaztak hosszabb időn keresztül, aminek során TEF alakult ki. A képalkotó vizsgálatokon jól látható a túlfújt ballon. A mellkasröntgen-felvételen 3,5 cm átmérőjü hiperinflált ballon volt látható (6. ábra). A CT-felvételen a trachea $1,5 \mathrm{~cm}$-es szakaszán nem tudták azonosítani a falát, mellette pneumomediastinumot diagnosztizáltak. A CT-felvétel mutatta a közös üreget, amely egybenyílva biztosította a teret a túlfújt ballonnak. Nyaki feltárásból a trachea primer suturája történt. Posztoperatíven antibiotikum indult, mediastinitis nem fejlődött ki.

\section{Megbeszélés}

A légúti sérüléseknek számos oka lehet; a leggyakrabban iatrogén úton vagy trauma kapcsán jönnek létre, a trachea cervicalis szakasza ilyen szempontból rendkívül sérülékeny. Trauma során a betegek többsége tompa mellkasi vagy nyaki sérülést szenved, jellemző mechanizmus a direkt erőbehatás vagy a hirtelen hiperextenzió. Tipikus sérülési mechanizmus, amikor a légcső direkt erő hatására a nyelőcsőhöz és a csigolyákhoz préselődik. Ilyen sérülést okozhat például a magasan húzódó biztonsági öv, ahogyan azt első betegünknél tapasztaltuk.

Nehéz intubálás közben szintén létrejöhet tracheobronchialis sérülés. A leggyakrabban RSI során a tubus

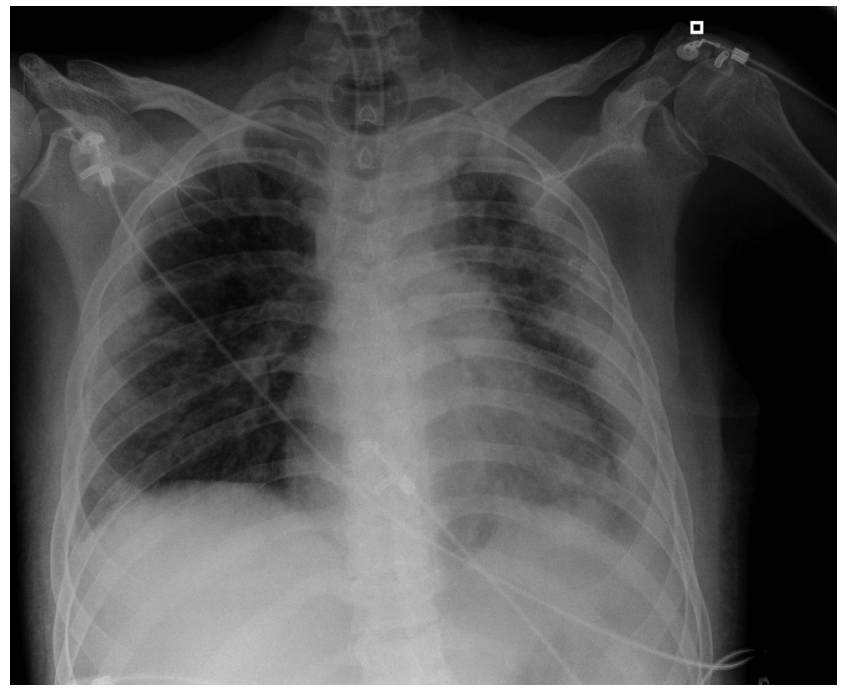

6. ábra

Röntgenfelvételen látható túlfújt ballon a harmadik esetben

vége vagy a hirtelen, túlzottan felfújt cuff okozhatja a rupturát. Hajlamosító tényező a többszöri intubációs kísérlet, a tubus újrapozicionálása a mandzsetta nem megfelelő deflációjával, köhögés, nagy méretű tubus, nem megfelelően alkalmazott vezetőnyárs, illetve a fej vagy a nyak hirtelen mozgatása [2]. A laesio döntően a hátulsó hártyás falon alakul ki, ahol a $\mathrm{C}$ alakú porcok védőhatása már nem érvényesül. Nőknél szignifikánsan gyakoribb a sürgősségi intubáció utáni légcsősérülés, ami a gyengébb hátulsó fal és az eltérő anatómia miatt lehetséges (például relatíve rövidebb trachea) [3]. A trauma miatt kialakult sérülés szintjében az intubálás során felfújt ETT-ballon a laesiót súlyosbíthatja, a ballon átrepesztheti a trachea falát, és túlfúvódik a légúton kívülre.

Meg kell említeni a hosszan tartó intubációs időt is, ami TEF létrejöttéhez vezethet. A több mint 12 napig (12 és 200 nap között, átlag 40 napig) tartó intubáció, fóként nasogastricus szondával együtt, TEF kialakulására hajlamosít. Számos hajlamosító tényezőt ismerünk, ilyen többek között a tubus elmozdulása, infekció, szteroid, hipotenzió, időskor, diabetes. A TEF kialakulásának egyik legjelentősebb oka azonban a nagy nyomású ETTballon, amely a trachea falát a szondához nyomja. Ezen a helyen ischaemia, necrosis, majd fistula alakul ki [4]. Mind a traumás betegek intubálásakor, mind a hosszan tartó intubációs esetekben a mandzsetta hiperinflációja nyomásméréssel megelőzhető lehet. Az ajánlott érték 20 és $30 \mathrm{H}_{2} \mathrm{Ocm}$ között van; az ennél magasabb nyomás a kapilláris keringést gátolja, ezzel ischaemiát okozhat [5]. Az ellenőrző ballon tapintása nem elégséges a cuff nyomásának ellenőrzésére, mivel az esetek nagy részében a helyszíni intubációk során túl magas nyomással kerül felfúvásra $[6,7]$. A fentiek miatt fontos a mentőszemélyzet felkészítése a posztintubációs szövődményekre és főként azok megelőzésére. Az intubáció során a megfelelően kiválasztott tubusméret, a cuffnyomás mérése, a cuff leengedése a tubus mozgatása előtt, illetve a túlzott erőbevi- 
tel és a hirtelen manőverek kerülése a légcsősérülés veszélyét csökkenthetik.

A tracheobronchialis sérülések diagnosztikája sokszor nehézségekbe ütközik az atípusos tünetek és radiológiai jelek miatt. A fizikális vizsgálat során a leggyakrabban nehézlégzés, haemoptysis látható. A stridor vagy rekedtség a tracheát érintő sérülés korai jelei lehetnek. A fent említett tünetek azonban nem elég specifikusak a betegségre nézve. Emellett a társuló súlyos, akár életveszélyes sérülések elfedhetik a tüneteket. Cervicalis trauma során a leggyakrabban a nyelőcső, a nyaki nagyerek, a nervus laryngeus recurrens, a nyaki csigolyák, illetve a gége sérülésére számíthatunk.

A fizikális vizsgálat során a tracheobronchialis sérülések klasszikus jele a progresszív subcutan emphysema, amely a hasfalra, akár a végtagokra is ráterjedhet. Fokozatosan szélesedő, extrém kiterjedt subcutan emphysema esetén a légúti sérülés lehetősége mindig fel kell, hogy merüljön. Ám nem minden esetben van jelen emphysema. A környező lágyrészek még teljes légcsőruptura esetén is fedhetik a csonkot, megakadályozva ezzel a levegőnek a szövetekbe terjedését. A fistulára nem jellemző az emphysema, ezért TEF során aspiráció vagy a gyomor indokolatlan disztenziója lehet az első tünet.

Általánosságban elmondható, hogy képalkotók segítségével a légcsősérülés direkt vizualizációja csak ritkán lehetséges, indirekt jelekből azonban lehet rá következtetni. Az Advanced Trauma Life Support (ATLS) legfrissebb, 10. kiadásában a primer ellátás részét képezi az eFAST- (Extended Focused Assessment with Sonography in Trauma) vizsgálat [8]. E szerint a mellkas ultrahangvizsgálata során a klinikus képes kimutatni a légmell jelenlétét. Bár a subcutan emphysema korlátozhatja a vizsgálatot, ezekben az esetekben utalhat is a légút sérülésére. Nyaki és mellkas-röntgenfelvételeken a legtöbbször súlyos lágyrész-emphysema, pneumomediastinum, esetenként pneumothorax látható. A nyaki, illetve mellkasi MDCT- (multi-slice detector computed tomography) felvétel a leginformatívabb radiológiai vizsgálat, ám itt is szintén ezek a jelek (emphysema, pneumomediastinum, pneumothorax) dominálnak. Esetleg a trachealis légsáv elmosódása, megszakadása vagy paratrachealis légsáv jelenhet meg. Mindezek alapján a negatív CT nem zárja ki a légcsősérülés lehetőségét [9-11]. Segítségünkre lehet a háromdimenziós rekonstrukció vagy a virtuális bronchoszkópia is a diagnózisban. Amennyiben a nyelőcsősérülés lehetősége is felmerül, kontrasztanyagos oesophagographia elvégzése igazolhatja a trachea hátsó falának rupturáját.

A fentiek mellett azonban a légúti sérülések diagnosztikájában a fiberoszkópos vizsgálat az „arany standard” eljárás [9]. Számos előnye van a CT-vizsgálattal szemben: gyors, egyszerú, és pontosabb képet adhat a sérülés helyéről, kiterjedéséről. Amennyiben a ruptura helye az endotrachealis ballon szintjében helyezkedik el, elképzelhető, hogy a fiberoszkópos vizsgálat nem látja a laesiót.
Ezek alapján látható, hogy a gondos kivizsgálás ellenére is nehéz a diagnózis felállítása, és az gyakran indirekt radiológiai jeleken és tüneteken alapul. Cikkünkben szeretnénk rávilágítani a légúti sérülés mentén túlfújt ETTmandzsetta jelentőségére, ami pathognomicus jelnek számít, és akár röntgenfelvételen is mutathatja a légcsősérülés jelenlétét. A túlfújt ballon egy ritka, de egyértelmú jele a trachea laesiójának, ennek láttán számíthatunk arra, hogy a légcső teljes falvastagsága átrepedt a ballon szintjében [12-15]. Első betegünknél a trachea teljes szeparációja jött létre, míg a második esetben a hátrafelé herniálódó ballon a pars membranaceán keletkezett hosszanti repedés jele volt. TEF esetén a mediastinalis vagy subcutan emphysema megjelenése nem típusos, de a túlfújt ballon utalhat a diagnózisra. Ilyenkor a ballon a nyelő́csőbe nyomul be. A szakirodalomban említést tesznek arról, hogy a részben herniálódott ballon alakja deformálódhat, gömb helyett például homokóra vagy úgynevezett Miki egér-formát vesz fel, ahogyan második betegünknél is ezt láttuk [13].

Nem típusos esetekben a túlfújt ballon képe alapján merülhet fel a tracheobronchialis sérülés lehetősége, ennek alapján végezhetünk célzott bronchoszkópos vizsgálatot. Első betegünknél a fiberoszkópia megállapította ugyan, hogy a ballontól caudalisan, illetve cranialisan nem látható laesio, de nem segített hozzá a pontos diagnózishoz, és a további ellátás szempontjából irreleváns volt. A második betegnél, bár lokalizálta a sérülést, de a CT-felvételt áttekintve a trachea rupturája már a képalkotó alapján is jól látható volt. A felvételeken észlelt extratrachealis ballon miatt tehát a betegség láthatóvá vált, ráadásul mindkét esetben pontosan mutatta a laesio helyét is.

Mútét során a laesio helyétől függetlenül a primer rekonstrukció ajánlott. Nagyobb vagy teljes ruptura esetén a szélek reszekciója elkerülhetetlenné válhat, törekedni kell azonban a lehető legkisebb kimetszésre, fóként a carina közelében $[16,17]$. Kiterjedt sérülés esetén tracheostomia is szóba jöhet. Fontos az anastomosis feszülésmentes zárása, ha szükséges, a nyak néhány napos flexióban tartása tehermentesítheti a varratokat. Súlyos légúti sérülés kapcsán egy protektív réteget (pleura, pericardium, izomlebeny) helyezhetünk az anastomosis fölé, ezzel szeparálva a nyelőcsövet [17]. Kisebb TEF esetén sutura, kiterjedt fistula ellátásakor tracheareszekció és izomlebeny használata válhat szükségessé.

Néhány kivételes esetben a sebészeti megoldás mellett a konzervatív kezelés is elfogadott lehetőség. Bár nincs egységes protokoll erre nézve, a szakirodalom alapján ennek ajánlott kritériumai a következő́k lehetnek: a laesio kisebb, mint $2 \mathrm{~cm}$, vagy egyharmada a légcső átmérőjének; a beteg klinikailag stabil; spontán lélegzik, vagy minimális légzéstámogatást igényel; nincs jele mediastinitisnek vagy szepszisnek; nincs súlyos társsérülés $[1,16$, 17]. Dönthetünk a konzervatív és a sebészeti kezelés között annak alapján is, hogy a falvastagság mekkora részét érinti a sérülés. Cardillo és mtsai cikkükben kategorizál- 
ják és leírják a iatrogén tracheasérülések kezelési tervét: inkomplett sérülés vagy egyszerú komplett ruptura esetén konzervatív kezelés lehetséges. Komplett sérülés mediastinitisszel vagy a nyelőcső sérülésével társulva, illetve a trachea teljes szeparációjával járó sérülés esetén sebészeti kezelés ajánlott [18].

Konzervatív kezelés fooként iatrogén esetekben javasolt. Ajánlott antibiotikumterápia indítása, az ETT-ballonnak a sérüléstől distalisan történő pozicionálása, illetve a drenálás is megfontolandó. Azoknak a betegeknek, akik számára a mútét túl kockázatos, alternatív kezelési módszer lehet sztent behelyezése. Ez a technika elsősorban szintén iatrogén esetekben ajánlott, illetve jó eredményeket értek el a légcsősérülések következményeként kialakuló szükületek kezelésében [19]. Instabil, kritikus állapotú betegekkel kapcsolatban az elmúlt években egyre nagyobb számban publikálnak jó tapasztalatokat ECMO- (extracorporeal membrane oxygenation) kezeléssel [20].

\section{Következtetések}

Elmondható, hogy tompa mellkasi vagy nyaki trauma és nehéz intubáció során a légcső sérülésére gondolnunk kell, fóként, ha kiterjedt subcutan emphysema is jelen van. Hosszabb ideje tartó intubáció mellett szintén számolnunk kell a tracheasérülés lehetőségével. A diagnosztikus folyamat során gyakran az egyetlen egyértelmú jel a CT-n vagy röntgenen látható, túlfújt tubusmandzsetta, mely mutatja a légcső rupturáját, és így korai célzott fiberoszkópos vizsgálat végezhető.

Anyagi támogatás: A cikk elkészítése anyagi támogatásban nem részesült.

Szerzôi munkamegosztás: R. A: A közlemény megírása. O. A., B. B.: Adatgyújtés. K. T.: Szakirodalmi kutatás. F. J.: Az operációk elvégzése, a kézirat áttekintése, a szöveg szakmai véleményezése. A cikk végleges változatát valamennyi szerző elolvasta és jóváhagyta.

Érdekeltségek: A szerzőknek nincsenek érdekeltségeik.

\section{Irodalom}

[1] Linegar A, Schulenburg R. Tracheobronchial trauma. In Kużdżał J, Asamura H, Detterbeck FC, et al. (eds.) ESTS textbook of thoracic surgery. Vol 2. Medycyna Praktyczna, Cracow, 2015; pp. 937-943.

[2] Baranyai Zs, Kocsis Á, Jósa V. Successful surgical treatment of tracheal rupture caused by endotracheal intubation. [Endotra- chealis intubáció okozta trachearuptura sikeres sebészi ellátása.] Orv Hetil. 2010; 151: 946-949. [Hungarian]

[3] Fan CM, Ko PC, Tsai KC, et al. Tracheal rupture complicating emergent endotracheal intubation. Am J Emerg Med. 2004; 22: 289-293.

[4] Kaur D, Anand S, Sharma P, et al. Early presentation of postintubation tracheoesophageal fistula: perioperative anesthetic management. J Anaesthesiol Clin Pharmacol. 2012; 28: 114-116.

[5] Talekar CR, Udy AA, Boots RJ, et al. Tracheal cuff pressure monitoring in the ICU: a literature review and survey of current practice in Queensland. Anaesth Intensive Care 2014; 42: 761770.

[6] Peters JH, Hoogerwerf N. Prehospital endotracheal intubation; need for routine cuff pressure measurement? Emerg Med J. 2013; 30: 851-853.

[7] Rahmani F, Soleimanpour H, Zeynali A, et al. Comparison of tracheal tube cuff pressure with two techniques: fixed volume versus pilot balloon palpation. J Cardiovasc Thorac Res. 2017; 9: 196-199

[8] Thoracic trauma. In: Merrick C. (ed.) ATLS Advanced Trauma Life Support, Student Course Manual. Tenth edition. American College of Surgeons, Chicago, IL, 2018; pp. 62-81.

[9] Bagga B, Kumar A, Chahal A, et al. Traumatic airway injuries: role of imaging. Curr Probl Diagn Radiol. 2020; 49: 48-53.

[10] Cheng J, Cooper M, Tracy E. Clinical considerations for blunt laryngotracheal trauma in children. J Pediatr Surg. 2017; 52: 874-880.

[11] Santiago-Rosado LM, Sigmon DF, Lewison CS. Tracheal trauma. [Updated 2020 March 18.] In: StatPearls [Internet]. Treasure Island (FL), StatPearls Publishing, 2020. Available from: http://www.ncbi.nlm.nih.gov/books/NBK500015/ [accessed: January 26, 2019].

[12] Euathrongchit J, Thoongsuwan N, Stern EJ. Nonvascular mediastinal trauma. Radiol Clin North Am. 2006; 44: 251-258.

[13] Chen JD, Shanmuganathan K, Mirvis SE, et al. Using CT to diagnose tracheal rupture. Am J Roentgenol. 2001; 176: 12731280.

[14] Rollins RJ, Tocino I. Early radiographic signs of tracheal rupture. Am J Roentgenol. 1987; 148: 695-698.

[15] Scaglione M, Romano S, Pinto, A et al. Acute tracheobronchial injuries: impact of imaging on diagnosis and management implications. Eur J Radiol. 2006; 59: 336-343.

[16] Altinok T, Can A. Management of tracheobronchial injuries. Eurasian J Med. 2014; 46: 209-215.

[17] Zhao Z, Zhang T, Yin X, et al. Update on the diagnosis and treatment of tracheal and bronchial injury. J Thorac Dis. 2017; 9: E50-E56.

[18] Cardillo G, Carbone L, Carleo F, et al. Tracheal lacerations after endotracheal intubation: a proposed morphological classification to guide non-surgical treatment. Eur J Cardiothorac Surg. 2010; 37: 581-587.

[19] Shemmeri E, Vallières E. Blunt tracheobronchial trauma. Thorac Surg Clin. 2018; 28: 429-434.

[20] Biancosino C, Krüger M, Kühn C, et al. First successful surgical reconstruction of bilateral transected main bronchi with extracorporeal membrane oxygenation support. Ann Thorac Surg. 2016; 102: el35-e137.

(Rieth Anna dr., Szeged, Korányi fasor 14-15., 6725 e-mail: rieth.anna@med.u-szeged.hu)

A cikk a Creative Commons Attribution 4.0 International License (https://creativecommons.org/licenses/by/4.0/) feltételei szerint publikált Open Access közlemény, melynek szellemében a cikk bármilyen médiumban szabadon felhasználható, megosztható és újraközölhető, feltéve, hogy az eredeti szerző és a közlés helye, illetve a CC License linkje és az esetlegesen végrehajtott módositások feltüntetésre kerülnek. (SID_1) 